\title{
New Sequence Variations in Spermatogenesis Candidates Genes
}

\author{
María Noelia Polii, ${ }^{1,2,3}$, Pedro Fernández Iriarte ${ }^{1,2}$, Celia Iudica ${ }^{1,3}$, Justo Hector Mario Zanier ${ }^{3}$, Roberto Coco ${ }^{4}$ \\ ${ }^{1}$ Laboratorio de Genética, Departamento de Biología FCEyN, Universidad Nacional de Mar del Plata. Argentina \\ ${ }^{2}$ CONICET - The National Scientific and Technical Research Council. Argentina \\ ${ }^{3}$ Asociación de Genética Humana (AGHU) Mar del Plata. Argentina \\ ${ }^{4}$ FECUNDITAS Medicina Reproductiva afiliada a la Universidad de Buenos Aires. Argentina
}

This issue was part of the doctoral dissertation of Maria Noelia Poli, which was defended in the National University of Mar del Plata in April of 2014

\begin{abstract}
Objective: The aim of this paper was to estimate the frequency and types of mutations in key candidate genes involved in spermatogenesis, and their potential role as a cause of azoospermia /cryptozoospermia.

Patients and Methods: The sequencing of the coding region of genes DBY, RBMY, DAZ, CDY and BPY2, excluding the promoter region, was performed in a series of 25 patients with azoospermia or severe oligozoospermia without AZF microdeletions. The exon 3 from the DAZL gene (DAL3) was also sequenced. The sequences obtained were analyzed by ProSeq, DnaSP v5 and compared with the database using Blastn and tblastx.

Results: 16 of the 25 patients showed some type of variants, such as transversions, transitions, deletions and/or insertions in the DAZ, DAZL, CDY and RBMY genes. The mutated sequences had between 97 and 99\% homology with the specific protein of every gene, except the DAZL (73\%) and DAZ (94\%) proteins.

Conclusions: The variants found have not been described previously, suggesting they could be mutations that might affect protein function.
\end{abstract}

Keywords: Male infertility, Spermatogenesis candidate genes, New sequence variants

\section{INTRODUCTION}

It is well recognized that the regions called AZFa, AZFb and AZFc of the long arm of chromosome $Y$ are associated with azoospermia or severe oligozoospermia, because in that region there are several candidate genes for normal spermatogenesis (Simoni et al. 2004; Raicu et al., 2003; Sadeghi-Nejad \& Farrokhi, 2007)

The long arm of the $Y$ chromosome contains genes involved in male infertility (Stuppia et al., 2000). Some of them are DAZ, CDY, BPY2, RBMY and DBY. DBY (Dead box polypeptide $Y$ ) is located in the AZFa region (Ditton et al., 2004) and the RBMY (RNA-binding motif) is in AZFb (Skrisovska et al., 2007; Dreumont et al., 2010). On the other hand, DAZ (Deleted in Azoospermia), CDY1 (chromodomain Y1) and BPY2 (basic protein2) are located in AZFc (Sadeghi-Nejad \& Farrokhi, 2007). These genes are involved in spermatogenesis. Many of these genes have not been characterized yet, and their study is not used for infertility diagnosis.

A recent study has shown that CDY2 is overexpressed in patients with Sertoli cell syndrome, suggesting that this gene is located within a segment of the $Y$ chromosome which is important for sperm maturation, and it is overexpressed in patients with spermatogenic maturation arrest (Stahl et al., 2012). Furthermore, it was discovered that the BPY2 gene is deleted in some infertile patients, playing a probable role in male gametogenesis (Stuppia et al., 2000).
The DAZ gene has an autosomal homologue, DAZL (DAZ-like), on chromosome 3p24, which is highly homologous to the DAZ gene, with $83 \%$ similarity to the coding region of the CDNA. Both genes encode RNA binding proteins. It is believed that the DAZ gene appeared some 40 million years ago during primate evolution by transposition, reamplification, and loss of the ancestral autosomal gene DAZL. It has been suggested that more than $60 \%$ of undiagnosed male infertility could be due to recessive autosomal mutations. The DAZL gene appears to be an interesting candidate for autosomal recessive infertility. To date, DAZL mutations have not been reported yet; however, a single nucleotide polymorphism (SNP) in exon 3 of the DAZL gene has been identified in patients with azoospermia or severe oligozoospermia (Poongothai et al., 2009).

Our goal was to estimate the frequency and types of variants in candidate genes involved in spermatogenesis, in a series of 25 infertile men with azoospermia or severe oligozoospermia without Yq deletions or AZF microdeletions.

\section{MATERIALS AND METHODS}

Fragments of six genes (BPY2, DBY, DAZ, RBMY, CDY and DAZL) involved in spermatogenesis were sequenced from 25 patients with abnormal semen. All of them had azoospermia or severe oligozoospermia, these patients had normal karyotype and did not have AZF microdeletions in the Yq11region. The sequence involved in the coding regions of the aforementioned genes determines azoospermia or severe oligozoospermia when they are deleted (Sadeghi-Nejad et al., 2007) (Table 1).

The infertile men were referred to the Association of Human Genetics from Mar del Plata by different Reproductive Medicine Centers. All patients were informed that the sequencing of such candidate genes is not a routine genetic testing in the medical practice of male infertility and they expressed their consent in written.

The DNA extraction from peripheral blood leucocytes was performed according to the protocol described by Rada \& Taboada, 1998. Table 2 depicts the different primers used in the PCR reaction according to the suggestions from Krausz et al., 1999 and Umeno et al., 2006.

The final PCR reaction volume was $25 \mathrm{ml}$ constituted by 50ng of genomic DNA, $10 \mathrm{mM}$ dNTPs of primer $10 \mathrm{X}, 25 \mathrm{mM} \mathrm{MgCl} 2$, and $10 \mathrm{X}$ Buffer. $1 \mathrm{U}$ of Taq polymerase was used per tube. Cycling conditions were: 1- $94^{\circ} 10^{\prime}, 2$ - $94^{\circ} 30^{\prime \prime}, 3-56^{\circ} 1^{\prime}, 4-72^{\circ} 1^{\prime}, 5-72^{\circ} 10^{\prime}$. Steps 2,3 and 4 comprised 30 cycles. The amplified fragments were purified using the Biopur ${ }^{\circledR}$ kit and subsequently sequenced by Macrogen ${ }^{\mathrm{TM}}$. The sequences obtained were analyzed by ProSeq (Filatov, 2002), DnaSP v5 (Rozas et al., 2010) and compared with the database through Blastn and tblastx (in blast.ncbi.nlm.nih.gov). 
Table 1 . Details of the genes involved in spermatogenesis. Details of the genes involved in spermatogenesis and the length of the gene fragments analyzed. Quotations of the chromosomal variants described (HGVS and NCBI).

\begin{tabular}{|c|c|c|c|c|c|c|}
\hline GEN & ID & NM & $\begin{array}{l}\text { LENGTH } \\
(\mathbf{p b})\end{array}$ & $\begin{array}{c}\text { FRAGMENT } \\
\text { D E S I G N E D } \\
(\mathrm{pb})\end{array}$ & PROTEIN & $\begin{array}{c}\text { C H ROMOSO M E } \\
\text { VARIANTS } \\
\text { DESCRIBED }\end{array}$ \\
\hline BPY 2 & 9083 & _004678 & 1212 & 102 & $\begin{array}{l}\text { Basic Y2 testis-spe- } \\
\text { cific protein }\end{array}$ & $\begin{array}{l}\text { Redon 2006; } \\
\text { Perry 2008; } \\
\text { Locke 2006 }\end{array}$ \\
\hline BPY 2B & 442867 & _001002760 & 1206 & 102 & $\begin{array}{l}\text { Y2 testis-specific ba- } \\
\text { sic protein } \\
\text { - isoform B }\end{array}$ & $\begin{array}{l}\text { Redon 2006; } \\
\text { Perry 2008; } \\
\text { Locke 2006 }\end{array}$ \\
\hline BPY2C & 442868 & _001002761 & 1206 & 102 & $\begin{array}{c}\text { Basic testis-specific } \\
\text { protein } \mathrm{Y} 2 \\
-\mathrm{C} \text { isoform }\end{array}$ & $\begin{array}{l}\text { Redon 2006; } \\
\text { Perry 2008; } \\
\text { Locke 2006 }\end{array}$ \\
\hline RBMY1A1 & 5940 & _005058 & 1900 & 174 & $\begin{array}{c}\text { Proteins because of } \\
\text { A1 RNA } \\
\text { binding member }\end{array}$ & $\begin{array}{c}\text { Redon 2006; Perry } \\
\text { 2008; Locke 2006; } \\
\text { Sharp 2005; } \\
\text { Kim 2009 }\end{array}$ \\
\hline DAZL & 1618 & _001351.3 & 3054 & 130 & $\begin{array}{c}1 \text { and } 2 \text { isoforms } \\
\text { DAZL3 }\end{array}$ & $\begin{array}{c}\text { Conrad 2010; Park } \\
\text { 2010; Xu 2011; } \\
\text { Teague 2010; } \\
\text { Pang 2010 }\end{array}$ \\
\hline CDY1 & 9085 & _004680.2 & 2373 & 72 & $\begin{array}{l}\text { Chromodomain pro- } \\
\text { tein specific Y1 tes- } \\
\text { ticular - isoforms b }\end{array}$ & $\begin{array}{l}\text { Redon 2006; } \\
\text { McCarroll 2008; } \\
\text { Locke 2006; } \\
\text { Campbell 2011 }\end{array}$ \\
\hline DBY & 8653 & _004660 & 4488 & 148 & $\begin{array}{l}\text { DDX3Y ATP-depen- } \\
\text { dent RNA helicase } \\
\text { - isoform histone de- } \\
\text { methylase UTY } 4\end{array}$ & not found \\
\hline DAZ2 & 57054 & _001005785.2 & 3781 & 264 & $\begin{array}{l}\text { Protein } 2 \text { deleted in } \\
\text { azoospermia } \\
\text { - isoforms } 2 \text { and } 3\end{array}$ & $\begin{array}{c}\text { Redon 2006; Perry } \\
\text { 2008; Sharp 2005; } \\
\text { Locke 2006; } \\
\text { Matsuzaki 2009; } \\
\text { Mc Carroll 2008 }\end{array}$ \\
\hline DAZ3 & 57055 & _020364.3 & 3515 & 264 & $\begin{array}{c}3 \text { protein deleted in } \\
\text { azoospermia }\end{array}$ & $\begin{array}{c}\text { Redon 2006; Perry } \\
\text { 2008; Sharp 2005; } \\
\text { Locke 2006; } \\
\text { Matsuzaki 2009; } \\
\text { Mc Carroll 2008 }\end{array}$ \\
\hline
\end{tabular}

Table 2 . Sets of primers for sequencing and size of the product. Sequences of primers used for amplification of the spermatogenesis candidate genes and the size of their respective products.

\begin{tabular}{|c|c|c|c|}
\hline Locus & Primers & Sequence & PCR product size \\
\hline \multirow[t]{2}{*}{ DBY } & Forward & 5 'СTTACACTTGCAGACTITGC3' & \multirow[t]{2}{*}{ 192bp } \\
\hline & Reverse & 5 'TTTAGTGGTGGACAATCATC3' & \\
\hline \multirow[t]{2}{*}{ RBMY } & Forward & 5 'CGCATATAGTAATACACGAG3' & \multirow[t]{2}{*}{ 239bp } \\
\hline & Reverse & 5'TGCTITAATATCTGCTCGAG3' & \\
\hline \multirow[t]{2}{*}{ DAZ } & Forward & 5 'CTGGTGACTGAATTACAATG3' & \multirow[t]{2}{*}{ 317bp } \\
\hline & Reverse & 5 'GTTCATGATGTATGTTAAGG3' & \\
\hline \multirow[t]{2}{*}{ CDY } & Forward & 5'TCATACAATCCAATTGTACTGG3' & \multirow[t]{2}{*}{$132 \mathrm{bp}$} \\
\hline & Reverse & 5'TTCTATCCCTCGGGCTGAGCTC & \\
\hline \multirow[t]{2}{*}{ BPY2 } & Forward & 5 'CAGCGTATCATAGAAAATGT3' & \multirow[t]{2}{*}{ 142bp } \\
\hline & Reverse & 5 'AGTACTITATTTGCAGGTTCTG3' & \\
\hline \multirow[t]{2}{*}{ DAZL3 } & Forward & 5 ' GAATGCTGAATTITTACTCTTGAAG3' & \multirow[t]{2}{*}{$181 \mathrm{pb}$} \\
\hline & Reverse & 5 'CTCTATACGTGGCTAGAGTTC3' & \\
\hline
\end{tabular}


Table 3 . Findings from the variants with the sequencing of the genes DBY, RBMY, DAZ, DAZL, CDY and BPY2. Details of variants found in the sequencing of the genes involved in spermatogenesis. In cases of deletion and/or insertion, the specific amino acid where the reading frame shift is generated. (NC_00024.9). All variants found are not reported in the international literature.

\begin{tabular}{|c|c|c|c|c|c|}
\hline GENE & PATIENT & CHROMOSOME POSITION (pb) & FUNCTION & $\mathrm{db}$ SNP ALLELES & PROTEIN RESIDUE \\
\hline DAZ2 & 5 & 25338454 & $\begin{array}{l}\text { Reading frame shift } \\
\text { INSERT }\end{array}$ & A & $\begin{array}{l}\text { Tyr }[\mathrm{Y}] \\
\text { Ser }[\mathrm{S}]\end{array}$ \\
\hline DAZ3 & 5 & 26952837 & $\begin{array}{l}\text { Reading frame shift } \\
\text { INSERT }\end{array}$ & A & $\begin{array}{l}\text { Tyr }[\mathrm{Y}] \\
\text { Ser }[\mathrm{S}]\end{array}$ \\
\hline \multirow{3}{*}{ RBMY } & 3 & 23710770 & $\begin{array}{l}\text { Non-synonymous } \\
\text { reference }\end{array}$ & $\begin{array}{l}\mathrm{T} \\
\mathrm{A}\end{array}$ & $\begin{array}{l}\text { Phe }[\mathrm{F}] \\
\text { Ile }[\mathrm{I}]\end{array}$ \\
\hline & 15 & 23710816 & $\begin{array}{l}\text { Non-synonymous } \\
\text { reference }\end{array}$ & $\begin{array}{l}\mathrm{C} \\
\mathrm{G}\end{array}$ & $\begin{array}{l}\text { Phe [F] } \\
\text { Ile [I] }\end{array}$ \\
\hline & 15 & 23710848 & $\begin{array}{l}\text { Non-synonymous } \\
\text { reference }\end{array}$ & $\begin{array}{l}\mathrm{C} \\
\mathrm{G}\end{array}$ & $\begin{array}{l}\text { Leu }[\mathrm{L}] \\
\text { Val }[\mathrm{V}]\end{array}$ \\
\hline \multirow{7}{*}{ CDY } & 1 & 27770162 & $\begin{array}{l}\text { Non-synonymous } \\
\text { reference }\end{array}$ & $\begin{array}{l}C \\
G\end{array}$ & $\begin{array}{l}\text { Thr }[T] \\
\text { Arg }[R]\end{array}$ \\
\hline & 1 & 27770151 & $\begin{array}{l}\text { Reading frame shift } \\
\text { INSERT }\end{array}$ & C & $\begin{array}{l}\text { Gly [G] - Ser [S] } \\
\text { Gly [G] - ALA [A] }\end{array}$ \\
\hline & 1 & 27770157 & $\begin{array}{l}\text { Reading frame shift } \\
\text { INSERT }\end{array}$ & $\mathrm{T}$ & $\begin{array}{l}\text { Ser }[\mathrm{S}] \\
\text { Gln }[\mathrm{Q}]\end{array}$ \\
\hline & 1 & 27770156 & $\begin{array}{l}\text { Reading frame shift } \\
\text { DELETION }\end{array}$ & A-G & $\begin{array}{l}\text { Ser }[\mathrm{S}] \\
\text { Gln }[\mathrm{Q}]\end{array}$ \\
\hline & $\begin{array}{l}3-7-17- \\
21-23-24\end{array}$ & 27770161 & $\begin{array}{l}\text { Non-synonymous } \\
\text { reference }\end{array}$ & $\begin{array}{l}\mathrm{G} \\
\mathrm{A}\end{array}$ & $\begin{array}{l}\text { Gly [G] } \\
\text { Arg [R] }\end{array}$ \\
\hline & 21 & 27770160 & $\begin{array}{l}\text { synonymous } \\
\text { reference }\end{array}$ & $\begin{array}{l}\mathrm{A} \\
\mathrm{C}\end{array}$ & $\begin{array}{l}\text { Pro }[P] \\
\text { Pro }[P]\end{array}$ \\
\hline & $11-20-22$ & 27770157 & $\begin{array}{l}\text { Reading frame shift } \\
\text { DELETION }\end{array}$ & G & $\begin{array}{l}\mathrm{His}[\mathrm{H}] \\
\mathrm{Gln}[\mathrm{Q}]\end{array}$ \\
\hline \multirow{17}{*}{ DAZL } & 10 & 16635718 & $\begin{array}{l}\text { Non-synonymous } \\
\text { reference }\end{array}$ & $\begin{array}{l}\mathrm{T} \\
\mathrm{G}\end{array}$ & $\begin{array}{l}\text { Ile }[\mathrm{I}] \\
\text { Ser }[\mathrm{S}]\end{array}$ \\
\hline & $12-18$ & 16635641 & $\begin{array}{l}\text { synonymous } \\
\text { reference }\end{array}$ & $\begin{array}{l}A \\
G\end{array}$ & $\begin{array}{l}{[\operatorname{Ter}[*]]} \\
{[\operatorname{Ter}[*]]}\end{array}$ \\
\hline & 12 & 16635747 & $\begin{array}{c}\text { Non-synonymous } \\
\text { reference }\end{array}$ & $\begin{array}{l}\mathrm{C} \\
\mathrm{G}\end{array}$ & $\begin{array}{l}\text { Pro }[\mathrm{P}] \\
\text { Ala }[\mathrm{A}]\end{array}$ \\
\hline & 18 & 16635636 & $\begin{array}{l}\text { Non-synonymous } \\
\text { reference }\end{array}$ & $\begin{array}{l}A \\
G\end{array}$ & $\begin{array}{l}\text { Asn [N] } \\
\text { Asp [D] }\end{array}$ \\
\hline & 18 & 16635673 & $\begin{array}{l}\text { Non-synonymous } \\
\text { reference }\end{array}$ & $\begin{array}{l}A \\
G\end{array}$ & $\begin{array}{l}\text { Lys }[K] \\
\text { Arg }[R]\end{array}$ \\
\hline & 18 & 16635678 & $\begin{array}{l}\text { Non-synonymous } \\
\text { reference }\end{array}$ & $\begin{array}{l}A \\
G\end{array}$ & $\begin{array}{l}\text { Lys }[K] \\
\text { Glu }[\mathrm{E}]\end{array}$ \\
\hline & 18 & 16635757 & $\begin{array}{l}\text { Non-synonymous } \\
\text { reference }\end{array}$ & $\begin{array}{l}A \\
G\end{array}$ & $\begin{array}{l}\text { Lys }[K] \\
\text { Arg }[R]\end{array}$ \\
\hline & 18 & 16635644 & $\begin{array}{l}\text { Non-synonymous } \\
\text { reference }\end{array}$ & $\begin{array}{l}\mathrm{T} \\
\mathrm{G}\end{array}$ & $\begin{array}{l}\text { Asn }[\mathrm{N}] \\
\text { Lys }[\mathrm{K}]\end{array}$ \\
\hline & 18 & 16635656 & $\begin{array}{l}\text { Non-synonymous } \\
\text { reference }\end{array}$ & $\begin{array}{l}\mathrm{T} \\
\mathrm{G}\end{array}$ & $\begin{array}{l}\operatorname{Tyr}[\mathrm{Y}] \\
{[\operatorname{Ter}[*]]}\end{array}$ \\
\hline & 18 & 16635662 & $\begin{array}{l}\text { Non-synonymous } \\
\text { reference }\end{array}$ & $\begin{array}{l}\mathrm{T} \\
\mathrm{G}\end{array}$ & $\begin{array}{l}\text { Cys [C] } \\
\text { Trp [W] }\end{array}$ \\
\hline & 18 & 16635666 & $\begin{array}{l}\text { Non-synonymous } \\
\text { reference }\end{array}$ & $\begin{array}{l}\mathrm{T} \\
\mathrm{A}\end{array}$ & $\begin{array}{l}\text { Cys }[C] \\
\text { Ser }[S]\end{array}$ \\
\hline & 18 & 16635692 & $\begin{array}{l}\text { Non-synonymous } \\
\text { reference }\end{array}$ & $\begin{array}{l}\mathrm{C} \\
\mathrm{A}\end{array}$ & $\begin{array}{l}\text { Cys }[\mathrm{C}] \\
{[\operatorname{Ter}[*]]}\end{array}$ \\
\hline & 18 & 16635719 & $\begin{array}{c}\text { Non-synonymous } \\
\text { reference }\end{array}$ & $\begin{array}{l}\mathrm{G} \\
\mathrm{T}\end{array}$ & $\begin{array}{l}\text { Arg [R] } \\
\text { Ser [S] }\end{array}$ \\
\hline & 18 & 16635671 & $\begin{array}{l}\text { synonymous } \\
\text { reference }\end{array}$ & $\begin{array}{l}\mathrm{G} \\
\mathrm{A}\end{array}$ & $\begin{array}{l}\text { Glu [E] } \\
\text { Glu [E] }\end{array}$ \\
\hline & 18 & 16635695 & $\begin{array}{l}\text { synonymous } \\
\text { reference }\end{array}$ & $\begin{array}{l}\mathrm{C} \\
\mathrm{G}\end{array}$ & $\begin{array}{l}\text { Ser }[\mathrm{S}] \\
\text { Ser }[\mathrm{S}]\end{array}$ \\
\hline & 25 & 16635681 & $\begin{array}{l}\text { Non-synonymous } \\
\text { reference }\end{array}$ & $\begin{array}{l}A \\
G\end{array}$ & $\begin{array}{l}\text { Asn }[\mathrm{N}] \\
\text { Asp [D] }\end{array}$ \\
\hline & 25 & 16635695 & $\begin{array}{l}\text { synonymous } \\
\text { reference }\end{array}$ & $\begin{array}{l}A \\
G\end{array}$ & $\begin{array}{l}\text { Ser [S] } \\
\text { Ser [S] }\end{array}$ \\
\hline
\end{tabular}


Table 4. Types of variants found in the sequences of the gene fragments studied. Results of the sequencing of the genes studied and their relation with the type of semen abnormality.

\begin{tabular}{|c|c|c|c|c|c|c|c|}
\hline $\begin{array}{l}\text { INDI- } \\
\text { VIDUAL }\end{array}$ & SEMEN & CDY ID 9085 & $\begin{array}{l}\text { RBMY } \\
\text { ID } 5940\end{array}$ & $\begin{array}{l}\text { DAZ } \\
\text { ID } 57055 \\
\text { Y/O ID57054 }\end{array}$ & $\begin{array}{l}\text { DAZL } \\
\text { ID } \\
1618\end{array}$ & $\begin{array}{l}\text { BPY2 } \\
\text { ID } \\
9083\end{array}$ & $\begin{array}{l}\text { DBY } \\
\text { DAZ } \\
\text { ID } \\
8653\end{array}$ \\
\hline 1 & Azoospermia & $\begin{array}{l}\text { One non-synonymous } \\
\text { mutation } \\
\text { Reading frame shift } \\
\text { deletion insertion }\end{array}$ & - & - & - & - & - \\
\hline 2 & Azoospermia & - & - & - & - & - & - \\
\hline 3 & Azoospermia & $\begin{array}{l}\text { One non-synonymous } \\
\text { mutation }\end{array}$ & $\begin{array}{l}\text { One } \\
\text { non-synonymous } \\
\text { mutation }\end{array}$ & - & - & - & - \\
\hline 4 & Oligozoospermia & - & - & - & - & - & - \\
\hline 5 & Oligozoospermia & - & - & $\begin{array}{l}\text { Reading frame } \\
\text { shift } \\
\text { by insertion }\end{array}$ & - & - & - \\
\hline 6 & Oligozoospermia & - & - & - & - & - & - \\
\hline 7 & Oligozoospermia & $\begin{array}{l}\text { One non-synonymous } \\
\text { mutation }\end{array}$ & - & - & - & - & - \\
\hline 8 & Azoospermia & - & - & - & - & - & - \\
\hline 9 & Oligozoospermia & - & - & - & - & - & - \\
\hline 10 & Azoospermia & - & - & - & $\begin{array}{l}\text { One } \\
\text { non-synonymous } \\
\text { mutation }\end{array}$ & - & - \\
\hline 11 & Azoospermia & $\begin{array}{l}\text { Reading frame shift } \\
\text { by deletion }\end{array}$ & - & - & - & - & - \\
\hline 12 & Azoospermia & - & - & - & $\begin{array}{l}\text { One synonymous } \\
\text { mutation } \\
\text { One non-synony- } \\
\text { mous mutation }\end{array}$ & - & - \\
\hline 13 & Oligozoospermia & - & - & - & - & - & - \\
\hline 14 & Oligozoospermia & - & - & - & - & - & - \\
\hline 15 & Azoospermia & - & - & $\begin{array}{l}\text { Two } \\
\text { non-synonimous } \\
\text { mutations }\end{array}$ & - & - & - \\
\hline 16 & Azoospermia & - & - & - & - & - & - \\
\hline 17 & Azoospermia & $\begin{array}{l}\text { One non-synonymous } \\
\text { mutation }\end{array}$ & - & - & - & - & - \\
\hline 18 & Oligozoospermia & - & - & - & $\begin{array}{l}\text { Ten } \\
\text { non-synonymous } \\
\text { mutations } \\
\text { Three } \\
\text { synonymous }\end{array}$ & - & - \\
\hline 19 & Azoospermia & - & - & - & - & - & - \\
\hline 20 & Azoospermia & $\begin{array}{l}\text { Reading frame shift } \\
\text { by deletion }\end{array}$ & - & - & - & - & - \\
\hline 21 & Oligozoospermia & $\begin{array}{l}\text { One non-synonymous } \\
\text { mutation }\end{array}$ & - & - & - & - & - \\
\hline 22 & Oligozoospermia & $\begin{array}{l}\text { Reading frame shift } \\
\text { by deletion }\end{array}$ & - & - & - & - & - \\
\hline 23 & Azoospermia & $\begin{array}{l}\text { One non-synonymous } \\
\text { mutation }\end{array}$ & - & - & - & - & - \\
\hline 24 & Oligozoospermia & $\begin{array}{l}\text { One non-synonymous } \\
\text { mutation }\end{array}$ & - & - & - & - & - \\
\hline 25 & Azoospermia & - & - & - & $\begin{array}{l}\text { One } \\
\text { non-synonymous } \\
\text { mutation } \\
\text { One synonymous } \\
\text { mutation }\end{array}$ & - & - \\
\hline
\end{tabular}




\section{RESULTS}

Different variants have been observed in the DAZ, DAZL, CDY and RBMY genes, corresponding to transversions, transitions, deletions and/or insertions in the gene fragment studied. Table 3 summarizes the molecular findings.

No variations in BPY2 and DBY were observed in the sequences analyzed.

From the sequencing of the 6 key candidate genes from the 25 patients, 16 had some type of variant. All patients had a single gene mutated, except one patient with azoospermia who showed mutations in two genes (CDY and RBMY) (Table 4). The mutations were found in CDY, RBMY, DAZ andDAZL. There were no variations in the BPY2 and DBY in the analyzed sequences.

\section{CONCLUSIONS}

In this series we found 16 patients with some type of mutation. The DBY gene presents as a single copy and is only detected in male germ line cells, mainly spermatogonia (Ditton et al., 2004). The DBY gene fragment of 148pb appears to be the most conserved in man; however several SNPs were found, but outside of our fragment sequenced. Therefore, it would be interesting to evaluate other parts of the DBY gene sequence.

BPY2 is a family of multicopy genes, specifically expressed in spermatogonia, spermatocytes and round spermatids (Lahn \& Page 2000, Tse et al., 2003). The sequencing of the $102 \mathrm{pb}$ fragment did not allow to find mutations.

The DAZ gene corresponds to another family of multicopy genes, expressed in spermatogonia and implicated in the development of haploid gametes (Menke et al., 1997; Kee et al., 2009). This gene associated with azoospermia showed a mutation in a patient with oligozoospermia with a shift in the reading frame of the fragment studied $(264 \mathrm{pb})$. Although it is not possible to ensure that this change generates a negative effect on fertility, it alters the protein and its function. There are only two SNPs described in the DAZ2 gene, with little information about the possible effects on spermatogenesis.

The exon 3 of the DAZL gene (DAZL3) showed transversions and transitions in the sequences of four patients, three with azoospermia and one with oligozoospermia (Table 3$)$. The sequence obtained $(130 \mathrm{pb})$ from the patient with oligozoospermia had $73 \%$ of homology compared with the protein in the database, which could indicate impaired function and altered protein structure due to the presence of various synonymous and non-synonymous mutations (Table 4), but we cannot be sure whether the cause of the disorder is due to a particular mutation or to the sum of them.

The CDY gene, which is expressed in mature spermatids (Lahn et al., 2002), had mutations in ten patients (10/25: 40\%). All types of variants, transitions, transversions, insertions and/or deletions were observed (Table 3 ). Six patients (three with azoospermia and three with oligozoospermia) had the same non-synonymous mutation, with an adenine switched for guanine at position 27770161 of the $Y$ chromosome, replacing the amino acid arginine for glycine at the CDY protein. Furthermore, three patients (two with azoospermia and one with oligozoospermia) showed a reading frame shift by deletion of a guanine in position 27770157 . It is possible that these mutations affect the protein function, but proteomic studies should be carried out beforehand, to infer if these variants cause adverse effects on male fertility. Since this region presented the greatest variation in the sequences analyzed, it is likely that the terminal region of the protein encoded by this gene is more prone to mutate.

The RBMY gene belongs to a family of multicopy gene and it is expressed only in testis (Skrisovska et al., 2007; Dreumont et al., 2010). Two patients with azoospermia had non-synonymous mutations (Table 4). Four SNPs have been described in this gene, but the variants found in our patients were not coincident with the ones previously reported (Table 3 ).

From all patients analyzed, only one had non-synonymous mutations in more than one gene (RBMY and CDY) (Table 4), which could be the cause of azoospermia. SNPs for the RBMY, DAZ2, DAZL and DBY genes have been described; however, the mutations found in the patients analyzed (Table 3) did not match the SNPs described. Existing data on sequenced genes involved in spermatogenesis are still scarce and contradictory. We need further studies that reveal the relation between new sequences with spermatic quality and the functionality of the proteins they encode.

Summarizing, the type of mutations found in the sequencing of the fragment studied in this series do not match those described in the literature. Therefore, at present they only represent new sequences that need to be confirmed with further studies before confirming whether they are normal or pathogenic variants. Regarding the fragments of the genes studied in infertile patients, DBY and BPY2 were the most conserved while the CDY gene presented the highest number of sequence variants.

\section{Acknowledgements}

The authors would like to thank Dr. Marta Susana Gallego and Dr. Irene Larripa for their intellectually support.

\section{CONFLICT OF INTERESTS}

No conflict of interest have been declared.

\section{Corresponding author:}

María Noelia Poli

Laboratorio de Genética

Department of Biología FCEyN

Mar del Plata - Argentine

E-mail: noeliamdp@gmail.com

\section{REFERENCES}

Campbell CD, Sampas N, Tsalenko A, Sudmant PH, Kidd JM, Malig M, Vu TH, Vives L, Tsang P, Bruhn L, Eichler EE. Population-genetic properties of differentiated human copy-number polymorphisms. Am J Hum Genet. 2011;88 :317-32.

Conrad DF, Pinto D, Redon R, Feuk L, Gokcumen O, Zhang $Y$, Aerts J, Andrews TD, Barnes C, Campbell P, Fitzgerald T, $\mathrm{Hu}$ M, Ihm CH, Kristiansson K, Macarthur DG, Macdonald JR, Onyiah I, Pang AW, Robson S, Stirrups K, Valsesia A, Walter K, Wei J; Wellcome Trust Case Control Consortium, Tyler-Smith C, Carter NP, Lee C, Scherer SW, Hurles ME. Origins and functional impact of copy number variation in the human genome. Nature. 2010; 464:704-12.

Ditton HJ, Zimmer J, Kamp C, Rajpert-De Meyts E, Vogt $\mathrm{PH}$. The AZFa gene DBY (DDX3Y) is widely transcribed but the protein is limited to the male germ cells by translation control. Hum Mol Genet. 2004; 13(19):2333-41.

Dreumont N, Bourgeois CF, Lejeune F, Liu Y, Ehrmann IE, Elliott DJ, Stévenin J. Human RBMY regulates germline-specific splicing events by modulating the function of the serine/arginine-rich proteins $9 \mathrm{G} 8$ and Tra2-\{beta\}. J Cell Sci. 2010;123:40-50.

Filatov DA. ProSeq: A software for preparation and evolutionary analysis of DNA sequence data sets. Mol Ecol Notes. 2002; 2: 621-4. 
HGVS [site in the Internet]. Human Genome Variation Society, copyright@HGVS 2014 [updated 2015 May 01; cited 2013 March 04]. Available at: http://www.hgvs.org/

Krausz C, Bussani-Mastellone C, Granchi S, McElreavey K, Scarselli G, Forti G. Screening for microdeletions of Y chromosome genes in patients undergoing intracytoplasmic sperm injection. Hum Reprod. 1999;14:1717-21.

Kee $\mathrm{K}$, Angeles VT, Flores M, Nguyen HN, Reijo Pera RA. Human DAZL, DAZ and BOULE genes modulate primordial germ-cell and haploid gamete formation. Nature. 2009; 462:222-5

Kim JI, Ju YS, Park H, Kim S, Lee S, Yi JH, Mudge J, Miller NA, Hong D, Bell CJ, Kim HS, Chung IS, Lee WC, Lee JS, Seo SH, Yun JY, Woo HN, Lee H, Suh D, Lee S, Kim HJ, Yavartanoo M, Kwak M, Zheng Y, Lee MK, Park H, Kim JY, Gokcumen O, Mills RE, Zaranek AW, Thakuria J, Wu X, Kim RW, Huntley JJ, Luo S, Schroth GP, Wu TD, Kim H, Yang KS, Park WY, Kim H, Church GM, Lee C, Kingsmore SF, Seo JS. A highly annotated whole-genome sequence of a Korean individual. Nature. 2009; 460:1011-5.

Lahn BT, Page DC. A human sex-chromosomal gene family expressed in male germ cells and encoding variably charged proteins. Hum Mol Genet. 2000; 9:311-9.

Lahn BT, Tang ZL, Zhou J, Barndt RJ, Parvinen M, Allis CD, Page DC. Previously uncharacterized histone acetyltransferases implicated in mammalian spermatogenesis. Proc Natl Acad Sci U S A. 2002; 99:8707-12.

Locke DP, Sharp AJ, McCarroll SA, McGrath SD, Newman TL, Cheng Z, Schwartz S, Albertson DG, Pinkel D, Altshuler DM, Eichler EE. Linkage disequilibrium and heritability of copy-number polymorphisms within duplicated regions of the human genome. Am J Hum Genet. 2006; 79:275-90.

Matsuzaki H, Wang PH, Hu J, Rava R, Fu GK. High resolution discovery and confirmation of copy number variants in 90 Yoruba Nigerians. Genome Biol. 2009; 10:R125.

McCarroll SA, Kuruvilla FG, Korn JM, Cawley S, Nemesh J, Wysoker A, Shapero MH, de Bakker PI, Maller JB, Kirby $A$, Elliott $A L$, Parkin $M$, Hubbell $E$, Webster T, Mei R, Veitch J, Collins PJ, Handsaker R, Lincoln S, Nizzari M, Blume J, Jones KW, Rava R, Daly MJ, Gabriel SB, Altshuler D. Integrated detection and population-genetic analysis of SNPs and copy number variation. Nat Genet. 2008; 40:1166-74.

Menke DB, Mutter GL, Page DC. Expression of DAZ, an azoospermia factor candidate, in human spermatogonia. Am J Hum Genet. 1997; 60:237-41.

NCBI [site in the Internet]. USA: National Center for Biotechnology Information; c2009. [updated 2015 May 07; cited 2013 March 04]. Available at: http://www.ncbi.nlm. nih.gov/

Pang AW, MacDonald JR, Pinto D, Wei J, Rafiq MA, Conrad DF, Park $H$, Hurles ME, Lee C, Venter JC, Kirkness EF, Levy S, Feuk L, Scherer SW. Towards a comprehensive structural variation map of an individual human genome. Genome Biol. 2010; 11:R52

Park H, Kim JI, Ju YS, Gokcumen O, Mills RE, Kim S, Lee S, Suh D, Hong D, Kang HP, Yoo YJ, Shin JY, Kim HJ, Yavartanoo M, Chang YW, Ha JS, Chong W, Hwang GR, Darvishi $\mathrm{K}$, Kim H, Yang SJ, Yang KS, Kim H, Hurles ME, Scherer SW, Carter NP, Tyler-Smith C, Lee C, Seo JS. Discovery of common Asian copy number variants using integrated high-resolution array CGH and massively parallel DNA sequencing. Nat Genet. 2010; 42:400-5.

Perry GH, Yang F, Marques-Bonet T, Murphy C, Fitzgerald T, Lee AS, Hyland C, Stone AC, Hurles ME, Tyler-Smith C, Eichler EE, Carter NP, Lee C, Redon R. Copy number variation and evolution in humans and chimpanzees. Genome Res. 2008;18:1698-710.

Poongothai J, Gopenath TS, Manonayaki S. Genetics of human male infertility. Singapore Med J. 2009; 50:336-47.

Rada TA, Taboada LG. Métodos de obtención y purificación de ADN humano para su aplicación en Genética Molecular. Biofarbo. 1998; 6:63-7. Available at: http://www.ops.org. bo/textocompleto/rnbiofa98060610.pdf.

Raicu F, Popa L, Pompilia A, Cimponeriu D, Dan L, Iliaca E, Bracea L L, Marinescu B, Gavrila L. Screening for microdeletions in human $Y$ chromosome - AZF candidate genes and male infertility. J. Cell. Mol. Med. 2003;7: 43-8.

Redon R, Ishikawa S, Fitch KR, Feuk L, Perry GH, Andrews TD, Fiegler H, Shapero MH, Carson AR, Chen W, Cho EK, Dallaire S, Freeman JL, González JR, Gratacòs M, Huang J, Kalaitzopoulos D, Komura D, MacDonald JR, Marshall CR, Mei R, Montgomery L, Nishimura K, Okamura K, Shen F, Somerville MJ, Tchinda J, Valsesia A, Woodwark C, Yang F, Zhang J, Zerjal T, Zhang J, Armengol L, Conrad DF, Estivill $\mathrm{X}$, Tyler-Smith C, Carter NP, Aburatani H, Lee C, Jones KW, Scherer SW, Hurles ME. Global variation in copy number in the human genome. Nature. 2006; 444:444-54.

Rozas J, Librado P, Sánchez-DelBarrio JC, Messeguer X, Rozas R. Universitat de Barcelona. DNA Sequence Polymorphism: DnaSP [software]. Version 5.10.1. Barcelona: Universitat de Barcelona; 2010. Available at: http://www. ub.edu/dnasp/

Sadeghi-Nejad H, Farrokhi F. Genetics of azoospermia: current knowledge, clinical implications, and future directions. Part II: Y chromosome microdeletions. Urol J. 2007; 4:192-206.

Sharp AJ, Locke DP, McGrath SD, Cheng Z, Bailey JA, Vallente RU, Pertz LM, Clark RA, Schwartz S, Segraves R, Oseroff VV, Albertson DG, Pinkel D, Eichler EE. Segmental duplications and copy-number variation in the human genome. Am J Hum Genet. 2005; 77:78-88.

Simoni M, Bakker E, Krausz C. EAA/EMQN best practice guidelines for molecular diagnosis of $\mathrm{y}$-chromosomal microdeletions. State of the art 2004. Int J Androl. 2004; 27:240-9

Skrisovska L, Bourgeois CF, Stefl R, Grellscheid SN, Kister L, Wenter P, Elliott DJ, Stevenin J, Allain FH. The testis-specific human protein RBMY recognizes RNA through a novel mode of interaction. EMBO Rep. 2007; 8:372-9.

Stahl PJ, Schlegel PN. Genetic evaluation of the azoospermic or severely oligozoospermic male. Curr Opin Obstet Gynecol 2012; 24:221-8

Stuppia L, Gatta V, Fogh I, Gaspari AR, Grande R, Morizio E, Fantasia D, Pizzuti A, Calabrese G, Palka G. Characterization of novel genes in AZF regions. J Endocrinol Invest. 2000; 23:659-63.

Teague B, Waterman MS, Goldstein S, Potamousis K, Zhou 
S, Reslewic S, Sarkar D, Valouev A, Churas C, Kidd JM, Kohn $S$, Runnheim R, Lamers C, Forrest D, Newton MA, Eichler EE, Kent-First M, Surti U, Livny M, Schwartz DC. High-resolution human genome structure by single-molecule analysis. Proc Natl Acad Sci U S A. 2010; 107:10848-53.

Tse JY, Wong EY, Cheung AN, O WS, Tam PC, Yeung WS. Specific expression of VCY2 in human male germ cells and its involvement in the pathogenesis of male infertility. Biol Reprod. 2003; 69:746-51.
Umeno M, Shinka T, Sato $Y$, Yang XJ, Baba $Y$, Iwamoto $T$, Nakahori $Y$. A rapid and simple system of detecting deletions on the $Y$ chromosome related with male infertility using multiplex PCR. J Med Invest. 2006, 53:147-52.

Xu H, Poh WT, Sim X, Ong RT, Suo C, Tay WT, Khor CC, Seielstad M, Liu J, Aung T, Tai ES, Wong TY, Chia KS, Teo YY. SgD-CNV, a database for common and rare copy number variants in three Asian populations. Hum Mutat. 2011; 32:1341-9. 